\title{
Pendidikan Akhlak Menurut Syekh Kholil Bangkalan
}

\author{
Krida Salsabila \\ Institut Agama Islam Darussalam (IAID) Ciamis \\ Email: krida.salsabila15@gmail.com \\ Anis Husni Firdaus \\ Institut Agama Islam Darussalam (IAID) Ciamis \\ Email: anishf.cms@gmail.com \\ Received: December 16, 2017 | Accepted: March 17, 2018
}

\begin{abstract}
The research aims to elaborate the thoughts of Sheikh Kholil Bangkalan about moral education. This research is considered important considering the ethical problems faced by modern society are very serious. Sheikh Kholil Bangkalan is an Indonesian cleric whose thoughts, attitudes, and behavior have a significant influence on Muslims in the country, especially in Bangkalan Land. By using the content analysis method, this study produced a number of findings, that according to Syekh Kholil Bangkalan, one of the goals of education is to make learners have noble character, namely the change of behavior of learners to a better direction. The purpose of this education is at the same time a concrete form of the ultimate goal of education, that is, faith and piety to God Almighty.
\end{abstract}

\begin{abstract}
Abstrak
Penelitian bertujuan untuk mengelaborasi pemikiran Syeikh Kholil Bangkalan tentang pendidikan akhlak. Penelitian ini dipandang penting mengingat problem etika yang dihadapi masyarakat modern sangat serius. Syeikh Kholil Bangkalan adalah ulama Indonesia yang pemikiran, sikap, dan perilakunya memiliki pengaruh signifikan terhadap umat Islam di Tanah Air, khususnya di Tanah Bangkalan. Dengan menggunakan metode analisis isi, penelitian ini menghasilkan sejumlah temuan, yaitu salah satu tujuan pendidikan menurut Syekh Kholil Bangkalan ini adalah untuk menjadikan peserta didik memiliki akhlak yang mulia, yakni adanya perubahan perilaku peserta didik ke arah yang lebih baik. Tujuanb pendidikan ini sekaligus merupakan bentuk konkret dari tujuan pendidikan yang paling utama, yaitu iman dan takwa kepada Tuhan yang Maha Esa.
\end{abstract}

\section{Keywords}

Islamic education, akhlak, value, moral, character 


\section{Pendahuluan}

Secara empiris dan nyata, Islam sangat memperhatikan pola kehidupan umatnya, bahkan semenjak manusia dalam kandungan sampai lahir hingga tumbuh berkembang, Islam telah menetapkan tata cara kehidupan umatnya, maka tidak mengherankan jika Nabi Muhammad sendiripun menyatakan tujuan kerasulannya adalah untuk menyempurnakan akhlak. Sepanjang sejarah umat manusia, masalah akhlak juga selalu menjadi pokok persoalan, karena perilaku manusia secara langsung ataupun tidak langsung masih menjadi tolak ukur untuk mengetahui dan menilai perbuatan atau sikap mereka. Akhlak dalam kehidupan manusia menduduki tempat penting sekali dalam baik sebagai anggota masyarakat dan bangsa, sebab jatuh bangun, jaya hancurnya, sejahtera rusaknya suatu bangsa dan masyarakat dan tergantung pada akhlaknya. Apabila akhlaknya baik, maka baik pula lahir batinnya dan sebaliknya jika jelek akhlaknya, jelek pula lahir batinyya. Akhlak merupakan bagian penting yang tidak dapat dipisahkan dalam kehidupan manusia, tanpa akhlak, manusia akan hilang derajat kemanusiaannya sebagai makhluk yang mulia (Sirait, Siddik, \& Zubaidah, 2017, p. 550).

Masalah akhlak ini mendapatkan perhatian yang utama dalam ajaran Islam, karena betapa pentingnya akhlak, salah satu tugas Nabi Muhammad Saw adalah untuk memperbaiki akhlak manusia, supaya manusia memiliki perilaku yang baik dalam menjalani kehidupan di dunia. Masih banyak masyarakat yang masih mengalami krisis akhlak, hal ini terlihat dari banyaknya berbagai kasus yang dilakukan sebagian masyarakat dimuat di media cetak maupun media elektronik. Akhlak sebagai sesuatu kekuatan dari dalam diri yang berkombinasi antara kecenderungan pada sisi yang baik dan sisi yang buruk (Setiawan, 2017, p. 44) .

Saat agama Islam masih menjadi minoritas di Indonesia, akhlak masyarakat pada waktu itu sangatlah buruk, mereka yang belum memeluk agama Islam biasanya terjebak dalam kegiatan yang sia-sia ditambah lagi diantara mereka ada yang menyembah pohon, patung, bahkan ada yang menyembah Tuhannya dengan cara pesugihan atau pertumbalan, sehingga para tokoh-tokoh pembaharu dalam Islam bergerak demi memberantas penyimpangan akhlak di masyarakat.

Perjuangan para tokoh Islam bukan saja hanya memberantas penyimpangan akhlak tetapi juga berjuang merebut kemerdekaan Indonesia dari penjajah Belanda dan Jepang hingga akhirnya kemerdekaan dapat diraih dengan bersatunya para pemimpin bangsa dan para tokoh pembaharu seperti Soekarno, Soeharto, Cut Nyak Dien, Cut Meutia, Kapten Pattimura beserta tokoh dari kaum penjajah sendiri yang menentang penindasan yang dilakukan 
bangsanya kepada rakyat Indonesia. Termasuk juga tokoh-tokoh pembaharu dalam Islam seperti KH. Ahmad Dahlan, KH. Hasyim Asy'ari, KH. Abdul Halim Majalengka, dan lain sebagainya, mereka itu adalah salah satu tokoh pembaharu dalam Islam di Indonesia bahkan mereka juga pendiri ormas pada masa itu hingga sampai sekarang, seperti: Ormas Muhammadiyah, NU, Persis, sampai dengan PUI.

Tokoh-tokoh pembaharu dalam Islam itu yang mendirikan Ormas adalah mereka yang berjuang memperbaiki akhlak-akhlak masyarakat di Indonesia agar menjadi lebih baik lagi sehingga para orang tua, anak didik, dan lain sebagainya memiliki akhlak atau budi pekerti yang mulia kepada sesama umat muslim maupun non-muslim karena kita ini semuanya adalah ciptaan Tuhan yang Maha Esa. Para tokoh-tokoh Ulama Islam di Indonesia tidak akan ada, jika tidak ada yang mengajari mereka tentang pendidikan akhlak. Maka dari itu, awal mulanya pendidikan akhlak muncul berkat adanya salah satu tokoh ulama terbesar bahkan beliau diberikan gelar oleh pemerintah Indonesia dengan sebutan Syaikhuna, yang artinya Maha Guru atau biasa disebut gurunya para ulama.

Kemudian Syekh Kholil Bangkalan memiliki murid-murid terkemuka, salah satunya yaitu KH. Hasyim Asy'ari (Pendiri NU), Soekarno (Presiden pertama Indonesia) dan KH. Ahmad Dahlan (Pendiri Muhammadiyah). Pada kenyataannya masih banyak para pakar, tokoh, dan penulis yang banyak mengungkapkan sisi pemikiran tokoh ini, maka dengan demikian menjadi hal yang tidak dapat dipungkiri untuk dikaji lebih jauh pemikiran Syekh Kholil Bangkalan terkait dengan Pendidikan Akhlak.

\section{Metode}

Penelitian ini menggunakan pendekatan kualitatif dengan metode library research (studi pustaka), adapun teknik analisis data yang digunakan adalah content analisis atau analisis isi. Analisa data dapat juga dilakukan melalui tahapan display data, reduksi data, verifikasi data dan kesimpulan.

\section{Hasil dan Pembahasan}

Konsep Pendidikan Akhlak dari segi definitif bahwa menurut Syekh Kholil Bangkalan tidak lepas dari pemikiran gurunya yaitu Syekh Nawawi Al-Bantani, bahwa manusia pada prinsipnya terdiri dari dua dimensi yaitu dimensi materi (fisiologis) dan dimensi immateri (psikologis). Baik dimensi fisiologis maupun psikologis adalah satu kesatuan integral yang tidak dapat dipisahkan antara satu dengan yang lainnya dan keduanya saling melengkapi. Fitrah manusia 
menurutnya ialah fitrah ketuhanan (tauhid)-dualis dan aksinya terhadap dunia luar bersifat interaktif-responsif (Siregar, 2007, p. 250). Hal ini diperkuat oleh pendapat Salim bahwa pengertian Pendidikan adalah pendidikan mengenai dasar-dasar akhlak dan keutamaan perangai, tabi'at yang harus dimiliki dan dijadikan kebiasaan oleh anak sejak masa analisis sampai ia menjadi seorang mukallaf, seseorang yang telah siap mengarungi lautan kehidupan (Salim, 2001, pp. 56-58).

Dari definisi di atas dapat diketahui bahwa Pendidikan Akhlak menurut Syekh Kholil Bangkalan adalah pendidikan mengenai dasar-dasar akhlak dan Islam dalam rangka mencapai kemanusiaannya, sehingga mampu mengetahui hakikat penciptaannya sampai dengan mendapatkan kebahagiaan di dunia dan akhirat. Dengan demikian dapat dipahami bahwa Pendidikan akhlak itu merupakan suatu sikap atau kehendak manusia disertai dengan niat yang tentram dalam jiwa yang berlandaskan Alquran dan Al-Hadits yang daripadanya timbul perbuatan-perbuatan atau kebiasaan-kebiasaan secara mudah tanpa memerlukan pembimbingan terlebih dahulu. Jiwa kehendak jiwa itu menimbulkan perbuatan-perbuatan dan kebiasaan-kebiasaan yang bagus, maka disebut dengan akhlak yang terpuji. Begitu pula sebaliknya, jika menimbulkan perbuatan-perbuatan dan kebiasaan-kebiasaan yang jelek, maka disebut dengan akhlak yang tercela (Siregar, 2007, pp. 56-58).

Tujuan dari pendidikan akhlak Menurut Syekh Kholil Bangkalan adalah membentuk orang-orang yang bermoral baik, keras kemauan, sopan dalam bicara dan mulia dalam bertingkah laku dan perangai, bersifat bijaksana, sempurna, sopan dan beradab, ikhlas, jujur dan suci yang berlandasan Alquran dan Hadis. Dengan kata lain tujuan pendidikan akhlak bukan hanya mengetahui pandangan atau teori, bahkan setengah dari tujuan itu adalah mempengaruhi dan mendorong kehendak kita supaya membentuk hidup suci dan menghasilkan kebaikan dan kesempurnaan dan memberi faedah kepada sesama manusia. Tujuan utama dari pendidikan Islam ialah pembentukan akhlak dan budi pekerti yang sanggup menghasilkan orang-orang yang bermoral bukan hanya sekedar memenuhi otak murid-murid dengan ilmu pengetahuan tetapi tujuannya ialah mendidik akhlak dengan memperhatikan segi-segi kesehatan, pendidikan fisik dan mental, perasaan dan praktek serta mempersiapkan anak-anak menjadi anggota masyarakat (Bakhri, 2015, p. 53).

Maka dari itu akhlak berupaya untuk mendorong kehendak agar berbuat baik, akan tetapi ia tidak selalu berhasil kalau tidak ditaati oleh kesucian manusia. Syekh Kholil Bangkalan mengemukakan dua tujuan diberikannya pendidikan Islam bagi manusia, yaitu: a. Menjadi insan purna yang bertujuan mendekatkan diri kepada Allah Swt.; b. Menjadi insan purna yang bertujuan mendapatkan kebahagiaan dunia dan akhirat (Salim, 2001, pp. 56-58). 
Syekh juga dikenal di dunia tasawuf, ada sebuah ujaran yang sangat masyhur, "Barang siapa mengamalkan ilmu yang ia ketahui, maka Allah akan menganugrahkan kepadanya ilmu yang tidak pernah ia ketahui". Karena alasan ini pula lah beliau menjadi sosok yang tidak segan-segan membagi ilmu baik kepada santrinya maupun kepada masyarakat yang bertanya kepada beliau (Bakhri, 2015, p. 53).

Terlihat sangat kental sekali nuansa teologi atau ketauhidan dari pemikiran Syekh Kholil Bangkalan. Tidak hanya ditujukan dalam aktivitas kesehariannya, bahkan sampai merembet kepada pemikiran pendidikannya. Di atas juga sudah dipaparkan mengenai definisi pendidikan Islam yang sangat kental sekali nilai-nilai Ilahiyahnya. (Salim, 2001, pp. 56-58).

Dan sekarang merumuskan tujuan pendidikan Islam juga mengedepankan nilai-nilai ketuhanan. Dengan mengedepankan nilai-nilai tersebut, harapan semua manusia yang melaksanakan dan ikut dalam proses pendidikan selalu menjadi insan purna yang bertujuan selalu mendekatkan diri kepada Allah sehingga mendapatkan kebahagiaan dalam dunia dan akhirat, di samping itu, dalam Islam, tujuan pendidikan Islam yang dikembangkan adalah mendidik budi pekerti. Oleh karenanya, pendidikan budi pekerti dan akhlak merupakan jiwa dari pendidikan Islam. Mencapai suatu akhlak yang sempurna adalah tujuan yang sesungguhnya dari proses pendidikan. Pemahaman ini tidak berarti bahwa pendidikan Islam tidak memperhatikan terhadap pendidikan jasmani, akal, dan ilmu pengetahuan (science). Namun, pendidikan Islam memperhatikan segi pendidikan akhlak seperti memperhatikan segi-segi lainnya (Salim, 2001, pp. 56-58).

Yang hendak dikendalikan oleh akhlak ialah tindakan lahir. Akan tetapi oleh karena tindakan lahir itu tidak dapat terjadi bila tidak didahului oleh gerak batin atau tindakan hati, maka tindakan batin dan gerak-gerik hati termasuk lapangan yang diatur oleh akhlak. Tidak akan terjadi perkelahian kalau tidak didahului oleh tindakan batin atau gerak-garik hati, yakni bencimambenci (hasad). Oleh karena itu maka setiap insan diwajibkan dapat menguasai batinnya atau mengendalikan hawa nafsunya karena ialah yang merupakan motor dari segala tindakan lahir (Wajdi, 2016, pp. 69-70).

Aristoteles berkata, "Mengenai sesuatu yang berhubungan dengan keutamaan orang tidak hanya mengetahui, tetapi mesti ditambah dengan latihan untuk memiliki dan mempergunakannya atau menciptakan cara lain yang dapat menjadikan kita orang-orang yang utama. Kalau khotbah-khotbah dan kitab-kitab itu sanggup dengan sendirinya membuat kita menjadi orang baik-baik, maka pasti sebagaimana kata teognis setiap orang mau membelinya, walaupun dengan harga yang semahal-mahalnya. Tapi sayang seluruh kesanggupan dari dasar-dasar ilmu akhlak ini hanyalah memperkuat kemauan 
untuk tetap dalam kebaikan dan membuat hati mulia dengan fitrahnya utama (Wajdi, 2016, pp. 69-70)..

\section{Dasar Pendidikan Islam menurut Syekh Kholil Bangkalan}

Bertolak dari tujuan pendidikan akhlak yang telah dipaparkan, di sini juga dijelaskan tentang dasar-dasar pendidikan Islam menurut Syekh Kholil Bangkalan. Menurutnya menjadi sebuah kewajiban untuk dapat memahami sumber utama ajaran Islam yakni Alquran dan Al-Hadis. Karena hanya dengan mampu memahami secara menyeluruh teks sumber utama ajaran Islam itulah manusia akan mendapatkan khazanah keilmuan yang luas dan tanpa keluar dari jalur yang sudah tetera dalam ajaran Islam, terlebih-lebih tentang penddikan Islam (Bakhri, 2006: 67-73).

Dasar pentingnya akhlak dalam As-Sunah dijelaskan oleh Rasulullah Saw. dalam sabdanya: Dari Abu Hurairah r.a berkata: Bahwasanya Rasulullah Saw. bersabda "Sesungguhnya aku diutus hanyalah untuk menyempurnakan akblak yang baik". (HR. Ahmad dan Baihaqi). Dari ayat Al-Qur'an dan AsSunah Rasulullah Saw. di atas menunjukkan bahwa dasar dan pijakan pendidikan akhlak adalah Al-Qur'an dan Sunah Nabi. dari dasar dan pedoman itulah dapat diketahui kriteria suatu perbuatan itu baik ataupun buruk.

Sejalan dengan apa yang sudah dijelaskan di atas, bahwa Alquran dan Sunah Rasulullah Saw. (hadis) menjadi dasar utama dalam penyelenggaraan pendidikan Islam, karena menurutnya hanya berlandaskan Alquran dan AlHadis proses berjalannya pendidikan Islam pada suatu lembaga pendidikan. Dalam paragraf di bawah ini akan sedikit dipaparkan terkait dasar atau landasan yang digunakan sebagai acuan dan rujukan dalam proses penyelenggaraan pendidikan Islam yang sesuai dengan apa yang sudah dikemukakan oleh Syekh Kholil Bangkalan:

a. Alquran

Alquran adalah firman Allah Swt. berupa wahyu yang disampikan oleh Jibril kepada Rasulullah Saw. di dalamnya terkandung ajaran pokok yang dapat dikembangkan untuk keperluan seluruh aspek kehidupan melalui ijtihad. Ajaran yang terkandung dalam Alquran itu terdiri dari dua prinsip besar, yaitu yang berhubungan dengan masalah keimanan yang disebut aqidah, dan yang berhubungan dengan amal yang disebut syari'ah. (Bakhri, 2015, pp. 67-73).

Ajaran-ajaran yang berkenaan dengan iman tidak begitu banyak dibicarakan dalam Alquran, tidak sebanyak ajaran yang berkenaan dengan amal perbuatan. Hal ini menunjukkan amal yang seharusnya banyak dilakukannya, sebab semua amal perbuatan manusia dalam hubungannya dengan Allah Swt. dengan dirinya sendiri, dengan manusia sesamanya (masyarakat), dengan alam 
dan lingkungnnya, dengan makhluk lainnya, termasuk dalam ruang lingkup amal saleh (syari'ah) (Bakhri, 2015). (Bakhri, 2015, pp. 67-73).

Pendidikan akhlak, karena termasuk ke dalam usaha atau tindakan untuk membentuk manusia, termasuk ke dalam ruang lingkup mu'amalah, pendidikan akhlak sangat penting karena ia ikut menentukan corak dan bentuk amal dan kehidupan manusia, baik pribadi maupun masyarakat. Di dalam Alquran terdapat banyak ajaran yang berisikan tentang prinsip-prinsip berkenaan dengan kegiatan atau usaha pendidikan. (Bakhri, 2006: 67-73).

Sebagai contoh dapat dibaca kisah Luqman mengajari anaknya. Dalam Alquran Luqman ayat 12-19. Cerita ini menggariskan prinsip materi ilmu pengetahuan. Ayat lain menceritakan tujuan hidup dan tentang nilai suatu kegiatan amal saleh. Itu berarti bahwa kegiatan pendidikan Islam harus mendukung tujuan hidup tersebut. (Bakhri, 2006: 67-73).

Oleh karena itu, pendidikan Islam harus menggunakan Alquran sebagai sumber utama dalam merumuskan berbagai teori tentang pendidikan Islam. Dengan kata lain, pendidikan Islam harus berlandaskan ayat-ayat Alquran yang penafsirannya dapat dilakukan berdasarkan ijtihad yang disesuaikan dengan perubahan dan pembaharuan. (Bakhri, 2006: 67-73).

b. Sunah Nabi

As-Sunah ialah perkataan, perbuatan ataupun pengakuan Rasulullah Saw. yang dimaksud dengan pengakuan itu adalah kejadian atau perbuatan orang lain yang diketahui oleh Rasulullah Saw. dan beliau membiarkan saja kejadian atau atau perbuatan itu berjalan. Sunah merupakan sumber ajaran kedua setelah Alquran. Seperti Alquran, Sunah juga berisi tentang akidah dan syari'ah. Sunah berisi petunjuk (pedoman) untuk kemaslahatan hidup manusia dalam segala aspeknya, untuk membina umat menjadi manusia seutuhnya atau muslim yang bertakwa. (Bakhri, 2006: 67-73).

Oleh karena itu Sunah merupakan landasan kedua bagi cara pembinaan pribadi manusia muslim. Sunah selalu membuka kemungkinan penafsiran yang berkembang, itulah sebabnya, mengapa ijtihad perlu ditingkatkan dalam memahaminya termasuk Sunah yang berkaitan dengan pendidikan. (Bakhri, 2006: 67-73).

Di dalam Alquran banyak sekali ayat-ayat yang memerintahkan kita untuk melaksanakan pendidikan, selain itu di dalamnya banyak pelajaran yang bisa kita ambil dari kisah-kisah para Rasulullah Saw., sahabat dan lain sebagainya. Selain itu As-Sunah juga mempunyai fungsi yang sama. Selain Alquran dan As-Sunah, Syekh Kholil Bangkalan juga menggunakan dasar tentang pendidikan Islam adalah Qaul ulama' (Ijma ataupun Qiyas). (Bakhri, 2006: 67-73). 
Karena pada dasarnya Alquran masih memerlukan penafsiran-penafsiran kembali untuk merelevankan dengan situasi dan kondisi yang terjadi pada kehidupan manusia, tidak luput juga dalam dunia pendidikan. Alquran dan As-Sunah merupakan sumber hukum Islam dan merupakan pokok dari dasar pendidikan. Dari sinilah banyak para tokoh-tokoh pendidikan yang menggunakan Alquran dan As-Sunah sebagai dasar pendidikan Islam, salah satunya adalah Syekh Kholil Bangkalan. (Bakhri, 2006: 67-73).

\section{Sistem Pendidikan Menurut Syekh Kholil Bangkalan}

Pendidikan tidak hanya dibebani tugas mencerdaskan anak didik dari segi kognitif saja, akan tetapi kecerdasan dari segi afektif dan psikomotorik tugas harus diperhatikan. Dalam hal ini beban pendidikan yang berkaitan dengan kecerdasan afektif siswa adalah upaya membina moral (akhlak) peserta didik. Moral yang diharapkan adalah moral yang menjunjung tinggi nilai-nilai kemanusiaan yang disandarkan pada keyakinan beragama. Akan tetapi untuk mewujudkan hal tersebut dewasa ini tampaknya banyak kendala yang harus dihadapi. Munculnya isu kemerosotan martabat manusia (dehumanisasi) yang muncul akhir-akhir ini. Dapat diduga akibat krisis moral. Krisis moral terjadi antara lain akibat ketidak berimbangnya antara kemajuan "IPTEK" dan "IMTAQ". (Wajdi, 2016: 69-70).

Di lingkungan sekolah pendidikan pada kenyataannya dipraktekkan sebagai pengajaran yang sifatnya verbalistik. Pendidikan yang terjadi di sekolah formal adalah dikte, diktat, hafalan, tanya jawab, dan sejenisnya yang ujungujungnya hafalan anak di tagih melalui evaluasi tes tertulis. Kalau kenyataannya seperti itu berarti anak didik baru mampu menjadi penerima informasi belum menunjukkan bukti telah menghayati nilai-nilai Islam yang diajarkan.

Pendidikan akhlak seharusnya bukan sekedar untuk menghafal, namun merupakan upaya atau proses, dalam mendidik murid untuk memahami, mengetahui sekaligus menghayati dan mengamalkan nilai-nilai Islam dengan cara membiasakan anak mempraktekkan ajaran Islam dalam kesehariannya. Ajaran Islam sejatinya untuk diamalkan bukan sekedar di hafal, bahkan lebih dari itu mestinya sampai pada kepekaan akan amaliah Islam itu sendiri sehingga mereka mampu berbuat baik dan menghindari berbuat jahat.

Melihat fenomena tersebut masih banyak problem yang harus di selesaikan meliputi metode dan pendekatan untuk menyampaikan esensi dan klasifikasi ajaran Islam yang harus di utamakan. Ajaran Islam harus mencerminkan perilaku keseharian dan kepribadian sekaligus spiritualisme dalam hubungan antara manusia dan khalik-Nya.

Dalam bidang pendidikan akhlak, Syekh Kholil Bangkalan telah mendirikan beberapa pesantren dan pengajian-pengajian di tiap-tiap cabang 
dan ranting. Baik pada masa penjajahan Belanda maupun pada masa penguasa Jepang, K.H Kholil Bangkalan tetap memajukan pesantren-pesantren serta mengadakan tabligh dan pengajian-pengajian. Hal itu berkat adanya sistem pendidikan akhlak yang digunakan oleh Syekh Kholil Bangkalan, sistem pendidikan akhlak yang digunakan Syekh Kholil Bangkalan adalah menggunakan metode akhlak seorang Akhlak Murid dalam Belajar, Akhlak Murid kepada Guru, dan Guru dalam mengajar, antara lain:

1. Akhlak Murid dalam Belajar

Di usianya yang belia, Syekh Kholil Bangkalan belajar di pesantren yang diasuh oleh ayahnya, KH. Abdul Latief yang mana masih menerapkan pendidikan ma'hadiyah (pendidikan asli pesantren) yang menggunakan kurikulum salafiyah (tradisional) yang menitikberatkan pada penguasaan ilmuilmu diniyah keagamaan. (Bakhri, 2016: 13).

Semasa kecil Syekh Kholil Bangkalan dididik oleh ayahnya dengan materi spriritual dahulu sebelum materi yang lainnya. Karena akhlak seseorang yang sudah dewasa sebagian besar ditentukan oleh pendidikan yang ia terima sewaktu kecil. Jika masa kecilnya sudah dididik dengan ilmu keagamaan maka tidak dapat dipungkiri jika nantinya ia akan menjadi sosok manusia yang taat kepada Allah Swt. Selain itu peran orang tua juga sangat penting sebab orang tua adalah sekolah pertama bagi anak-anaknya.

Senada dengan pendapat Ulwan (2007: 184) ia mengatakan bahwa agar anak senantiasa mengingat Allah, hendaknya anak ditekankan untuk mempelajari pemikiran-pemikiran yang dapat mendekatkan dirinya kepada penciptanya. Cara pengajaran seperti ini telah diterapkan oleh salaf zaman dahulu dalam mengajarkan anak-anak mereka. Jika para pendidik, ayah atau ibu menerapkan cara dan dasar pendidikan ini, tidak mustahil bila dalam waktu yang relatif singkat mereka sudah dapat menciptakan suatu generasi muslim yang militan, bangga dengan agamanya, sejarah dan para pahlawannya yang mulia. Sehingga tercipta suatu masyarakat yang bersih dari kekufuran, kedengkian, dan tindak kejahatan yang penuh dengan dosa.

Pendidikan Kholil kecil didapat dari didikan ayahnya, yang mana seorang ayah adalah keluarga yang termasuk ke dalam salah satu faktor yang dapat memberi pengaruh kepada kepribadian anak. sebagaimana yang diutarakan Yaqub (1983: 67), manusia yang berasal dari satu keturunan di mana dan pembawaan yang bersamaan, misalnya bentuk badan, perasaan, akal dan pemikiran. Dengan sifat-sifat manusia yang diwariskan dari satu nenek moyang, maka manusia dapat menundukkan alam, sedangkan keistimewaan itu tidak diwariskan (diturunkan) kepada hewan karena berlainan keturunan.

Dalam Alquran dikemukakan: 


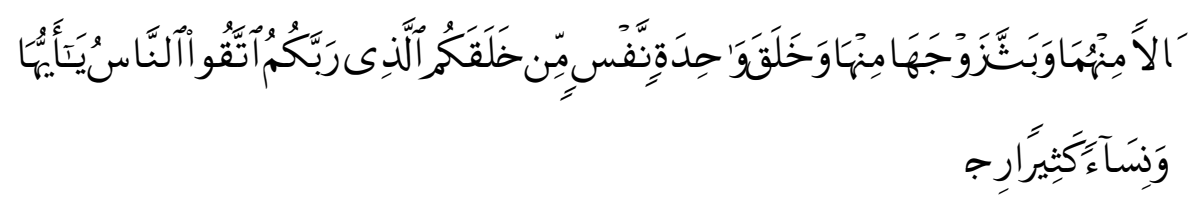

Hai sekalian manusia, bertakwalah kepada Tuhan-mu yang telah menciptakan kamu dari seorang diri, dan dari padanya Allah menciptakan istrinya; dan dari pada keduanya Allah memperkembangbiakkan laki-laki dan perempuan yang banyak. (QS. An-Nisa, 4: $1)$.

Seperti yang telah dijelaskan di awal bahwa materi pembelajaran yang pertama kali Syekh Kholil dapatkan dari didikan sang ayah adalah ilmu-ilmu diniyyah atau ilmu-ilmu keagamaan. Diantara ilmu yang diterima Syekh Kholil saat kecil adalah Fiqih, Tauhid, Akhlak, Tajwid, Tahsin, Nahwu dan Sharaf. Selain ilmu keagamaan juga beliau dibekali ilmu Matematika dan Sejarah. (Bakhri, 2015: 13).

Sejak kecil, Syekh Kholil sering diajak ayahnya menghadiri acara Diba'an yaitu sejarah ringkas mengenai keluhuran Rasulullah Saw. dan keluarganya melalui gubahan puitis. (Bakhri, 2015: 7).

Didikan yang diterima Syekh Kholil dari ayahnya saat masih adalah berupa ilmu-ilmu keagamaan, karena sebagaimana Firman Allah:

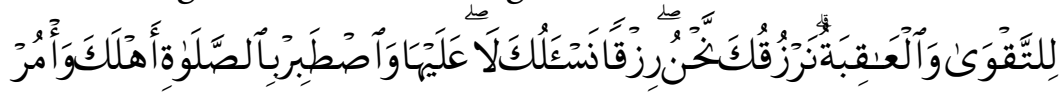

Dan perintahkanlah kepada keluargamu mendirikan shalat dan bersabarlah kamu dalam mengerjakannya. Kami tidak meminta rezki kepadamu, kamilah yang memberi rezki kepadamu. dan akibat (yang baik) itu adalah bagi orang yang bertakwa. (QS. Thaha, 20: 132)

Begitu pula dengan hadis Rasulullah Saw. yang artinya, "Perintahkanlah anak-anak kalian mengerjakan shalat pada saat usia mereka tujuh tahun dan pukullah mereka pada saat telah mencapai usia sepuluh tahun dan pisahkanlah antara mereka dalam ranjang tidur mereka”. (H.R. Sunan Abu Daud).

Dalil di atas menunjukkan bahwa Allah menyuruh untuk mendirikan shalat kepada keluarga. Sebelum melakukan shalat tentunya harus dibarengi dengan ilmu dan pendidikan ilmu Fiqih yang diterima Syekh Kholil sudah sesuai dengan firman Allah.

2. Akhlak Murid kepada Guru

Untuk belajar dari seseorang Syekh Kholil tidak sembarangan memilih guru itu terbukti dari guru-guru yang dipilihnya seperti Abu Dzarrin, Kiai yang dikenal alim dan pakar tata bahasa Arab, Kiai Noerhasan bin Noerkhotim seorang alim pengajar Kitab besar seperti Kitab Ihya Ulumuddin, Shahih Bukhari, dan Shahih Muslim. (Bakhri, 2016: 16, 20). 
Rasulullah Saw. bersabda yang artinya, "Sesungguhnya diantara tanda hari kiamat adalah, ilmu diambil dari orang - orang kecil (yaitu ahli bid'ah)". (H.R. Ibnul Mubarak).

Berikut adalah perkataan ulama yang dikutip oleh Atsari (2009) yang berkaitan dengan hal tersebut: Ali bin Abi Thalib berkata, "Perhatikan dari siapa kamu mengambil ilmu ini, karena sesungguhnya ia adalah agama". Abdullah bin Mas'ud juga mengatakan, "Manusia akan selalu berada di atas kebaikan, selama ilmu mereka datang dari para sahabat Nabi Muhammad dan dari orang-orang besar (tua) mereka. Jika ilmu datang dari arah orang-orang kecil (ahli bid'ah) mereka, dan hawa nafsu mereka bercerai-berai, mereka pasti binasa".

3. Akhlak Seorang Guru

Seperti yang disampaikan Wajdi (2016: 71), "Hampir seluruh umurnya ia habiskan untuk berdakwah dan mengajar para santri. Karena keikhlasannya menyebarkan ilmu agama, Allah mengangkat derajatnya dan mengaruniainya berbagai kenikmatan".

Seperti yang telah dijelaskan sebelumnya bahwa seseorang akan memperoleh apa yang diniatkannya dan niat mengajar Kholil adalah mengharapkan keridhaan Allah, karena niat itulah Syekh menjadi seorang Waliyullah dan hamba yang disayangi Allah. 2016: 69-70).

Ini terjadi ketika Syekh Kholil sedang mengajarkan kitab Jurmiyah kepada santrinya, hal tak terduga terjadi ketika tiba-tiba datang para petani mereka mengeluh seraya berkata, "Tolonglah Kiai, berikan kami do'a agar kami tahu apa penyebab hilangnya timun-timun itu!", mata Syekh Kholil mengarah kepada suatu kalimat dari kitab yang baru diajarkannya dan mendapati kata "Qaama Zaidun" yang artinya Zaid berdiri. Kemudian Syekh Kholil berkata, "Karena pelajaran kita telah sampai pada "qaama zaidun", maka do'anya ini saja”. Para petani pun wirid dengan do'a itu meskipun tidak mengerti apa arti kalimat ini. Esoknya, mereka menyaksikan pencuri timun itu sudah berdiri kaku di tempat masing-masing. (Wajdi, 2016: 69-70).

Dari peristiwa di atas ketika Syekh Kholil sedang sibuk mengajar maka didatangi para petani. Memperhatikan apa yang dikeluhkan petani menunjukkan kepeduliannya terhadap masyarakat dan meskipun beliau berilmu tinggi, namun beliau memberikan solusi yang mudah dilakukan bagi para petani tersebut. Beliau mengamalkan apa yang disabdakan Rasulullah Saw. yang diriwayatkan oleh Muslim: "mudahkanlah, janganlah mempersulit dan berikanlah kabar gembira dan janganlah membuat manusia lari”, dan hadits lain "Barang siapa yang melepaskan satu kesusahan seorang mukmin, pasti Allah akan melepaskan darinya satu kesusahan pada hari kiamat. Barang 
siapa yang menjadikan mudah urusan orang lain, pasti Allah akan memudahkannya di dunia dan di akhirat”. (H.R. Muslim).

\section{Materi Pendidikan Akhlak Menurut Syekh Kholil Bangkalan}

Menurut Syekh Kholil Bangkalan, materi pengajaran yang diberikan di pesantren Tebuireng adalah lebih menitikberatkan kepada ilmu-ilmu agama dan bahasa Arab. Namun setelah ada perubahan sistem pendidikan yang ada di pesantren Bangkalan Madura, maka materi yang diajarkan dibagi menjadi dua, yaitu: (1) Materi-materi yang bersifat keagamaan dengan menggunakan bukubuku yang ditulis dengan bahasa Arab atau bahasa Alquran, misalnya seperti Alquran, bahasa Arab, Ushul Fiqh, Hadits, Kitab Kuning, dan lain-lain yang berhubungan dengan materi-materi keagamaan. (2) Kedua adalah materi yang bersifat umum, atau dengan kata lain materi-materi non-keagamaan dengan menggunakan buku-buku yang ditulis dengan bahasa latin, misalnya seperti membaca dan menulis bahasa latin, bahasa Indonesia, ilmu bumi, sejarah Indonesia, dan ilmu hitung. (Burhan, 2007: 126-128).

Selain membekali santrinya dengan ilmu-ilmu lahir (eksoterik) yang sangat ketat- santrinya juga tidak diperbolehkan boyong (pulang kampung) sebelum hafal seribu nadzamAlfiyah Ibn Malik. Dalam setiap dakwahnya maupun dalam menerima pengaduan permasalahan selalu dikaitkan dengan bait Alfiyah Ibn Malik, jika seseorang menanyakan soal aqidah, maka Syekh Kholil menjawab dengan bait Alfiyah, begitupun dengan permasalahan tasawuf dan fiqih beliau menjawab dengan bait-bait Alfiyah. (Bakhri, 2015: 80).

Bahkan pernah terjadi suatu ketika Syekh Kholil berada dalam suatu undangan, beliau memakan makanan langsung menggunakan tangannya tanpa menggunakan sendok lantas menuai kritikkan dari orang lain, langsung saja dengan senyuman Syekh menjawabnya dengan bait-bait Alfiyah. Sehingga dapat disimpulkan bahwa isi dari Alfiyah bisa mencakup berbagai solusi dari berbagai masalah yang timbul kehidupan mulai dari masalah yang sepele sampai yang rumit sebagaimana yang dicontohkan dalam kehidupan Syekh Kholil Bangkalan. Selain itu, beliau juga menggembleng santrinya dengan ilmu batin (Esoterik). (Bakhri, 2015: 80).

Dilihat dari segi individu pengaruh pendidikan akhlak yang disebar luaskan oleh Syekh Kholil Bangkalan sangat mempengaruhi sekali terhadap masyarakat umat Islam di Indonesia, karena dengan adanya teori-teori Syekh Kholil Bangkalan para orang tua ataupun seorang pendidik yang memiliki Ilmu agama bisa mendidik seorang anak dan mengajarkan seorang anak tentang bagaimana berperilaku terhadap orang tua, ataupun terhadap orang disekitarnya. 
Para orang dewasa, maupun yang sudah berkeluarga seharusnya bisa memberikan kontribusi atau contoh kepada pihak yang muda bagaimana cara bersikap yang baik dan berakhlak mulia, maka dari itu dengan adanya ajaranajaran Syekh Kholil Bangkalan, para pendidik atau para orang-orang dewasa harus bisa memberikan kontribusi-kontribusi yang baik terhadap yang pihak yang muda sehingga ketika pihak yang muda sudah beranjak dewasa mereka akan memberikan contoh-contoh yang baik terhadap orang-orang di sekitarnya.

Analisis penelitian ini menggunakan data primer dan sekunder yang mana data-data tersebut diambil dari buku karangan atau karya dari seorang tokoh yang dibahas dan dari sumber-sumber buku yang bersangkutan. Proses analisis data ini dimulai dengan menelaah seluruh data yang diperoleh penulis dari berbagai macam sumber. Untuk mendapatkan kesimpulan dalam penelitian ini setelah dilakukan pengumpulan data, maka selanjutnya adalah melakukan analisis, bentuk teknik dalam analisis data ini dengan menggunakan analisis data deskriptif yang mana analisis deskriptif itu adalah usaha untuk mengumpulkan dan menyusun suatu data, kemudian dilakukan analisis terhadap data tersebut”. (Surakhmad, 1990: 139).

Dari definisi di atas dapat disimpulkan bahwa analisis deskriptif adalah menggambarkan atau menjelaskan data-data yang telah dikumpulkan baik itu berupa kata-kata, dan bukan angka-angka. Kemudian apa yang sudah dikumpulkan menjadi kunci terhadap apa yang sudah diteliti, dengan demikian laporan penelitian akan berupa kutipan-kutipan data dan pengolahan data untuk memberikan gambaran penyajian laporan tersebut, kemudian penulis memberikan penyimpulan dari masing-masing kutipan data yang diambil dari sumber data tersebut. Metode penelitian ini memiliki ciri-ciri sebagai berikut: a. Memusatkan diri pada pemecahan masalah; b. Data-data yang dikemukakan mula-mula disusun, dijelaskan, kemudian dianalisis.

Tujuan menggunakan metode deskriptif analisis adalah untuk mendeskripsikan secara rinci tentang objek penelitian ini bisa dilakukan tanpa hipotesis yang telah dirumuskan secara ketat. Dalam menyusun skripsi ini penulis menggunakan pendekatan metode analisis, dengan langkah-langkah sebagai berikut: 1) kategorisasi: membuat kategori-kategori dari masing-masing tulisan itu kemudian memilah-milah dan memisahkannya ke dalam sub-sub pemikiran; 2) Editing: Pemeriksaan kembali terhadap kelengkapan jawaban yang telah diperoleh.

Pengertian Pendidikan Akhlak Syekh Kholil Bangkalan tidak lepas dari pemikiran gurunya yaitu Syekh Nawawi Al-Bantani, bahwa manusia pada prinsipnya terdiri dari dua dimensi yaitu dimensi materi (fisiologis) dan dimensi immateri (psikologis). Baik dimensi fisiologis maupun psikologis 
adalah satu kesatuan integral yang tidak dapat dipisahkan antara satu dengan yang lainnya dan keduanya saling melengkapi. Fitrah manusia menurutnya ialah fitrah ketuhanan (tauhid)-dualis dan aksinya terhadap dunia luar bersifat interaktif-responsif (Siregar, 2007, p. 250)

Hal ini diperkuat oleh pendapat Salim bahwa pengertian Pendidikan adalah pendidikan mengenai dasar-dasar akhlak dan keutamaan perangai, tabi'at yang harus dimiliki dan dijadikan kebiasaan oleh anak sejak masa analisa sampai ia menjadi seorang mukallaf, seseorang yang telah siap mengarungi lautan kehidupan (Salim, 2001, pp. 56-58).

Dengan demikian dapat dipahami bahwa Pendidikan akhlak itu merupakan suatu sikap atau kehendak manusia disertai dengan niat yang tenteram dalam jiwa yang berlandaskan Alquran dan Al-Hadis yang daripadanya timbul perbuatan-perbuatan atau kebiasaan-kebiasaan secara mudah tanpa memerlukan pembimbingan terlebih dahulu. Jiwa kehendak jiwa itu menimbulkan perbuatan-perbuatan dan kebiasaan-kebiasaan yang bagus, maka disebut dengan akhlak yang terpuji. Begitu pula sebaliknya, jika menimbulkan perbuatan-perbuatan dan kebiasaan-kebiasaan yang jelek, maka disebut dengan akhlak yang tercela (Salim, 2001, pp. 56-58).

Tujuan dari pendidikan akhlak Menurut Syekh Kholil Bangkalan adalah membentuk orang-orang yang bermoral baik, keras kemauan, sopan dalam bicara dan mulia dalam bertingkah laku dan perangai, bersifat bijaksana, sempurna, sopan dan beradab, ikhlas, jujur dan suci yang berlandasan Alquran dan Hadis. Dengan kata lain tujuan pendidikan akhlak bukan hanya mengetahui pandangan atau teori, bahkan setengah dari tujuan itu adalah mempengaruhi dan mendorong kehendak kita supaya membentuk hidup suci dan menghasilkan kebaikan dan kesempurnaan dan memberi faedah kepada sesama manusia. Tujuan utama dari pendidikan Islam ialah pembentukan akhlak dan budi pekerti yang sanggup menghasilkan orang-orang yang bermoral bukan hanya sekadar memenuhi otak murid-murid dengan ilmu pengetahuan tetapi tujuannya ialah mendidik akhlak dengan memperhatikan segi-segi kesehatan, pendidikan fisik dan mental, perasaan dan praktek serta mempersiapkan anak-anak menjadi anggota masyarakat (Bakhri, 2015, p. 53).

Maka dari itu akhlak berupaya untuk mendorong kehendak agar berbuat baik, akan tetapi ia tidak selalu berhasil kalau tidak ditaati oleh kesucian manusia. Syekh Kholil Bangkalan mengemukakan dua tujuan diberikannya pendidikan Islam bagi manusia, yaitu: a. Menjadi insan purna yang bertujuan mendekatkan diri kepada Allah Swt.; b. Menjadi insan purna yang bertujuan mendapatkan kebahagiaan dunia dan akhirat (Salim, 2001, pp. 56-58).

Bertolak dari tujuan pendidikan akhlak yang telah dipaparkan, di sini juga dijelaskan tentang dasar-dasar pendidikan Islam menurut Syekh Kholil 
Bangkalan. Menurutnya menjadi sebuah kewajiban untuk dapat memahami sumber utama ajaran Islam yakni Alquran dan Al-Hadis. Karena hanya dengan mampu memahami secara menyeluruh teks sumber utama ajaran Islam itulah manusia akan mendapatkan khazanah keilmuan yang luas dan tanpa keluar dari jalur yang sudah tetera dalam ajaran Islam, terlebih-lebih tentang penddikan Islam (Bakhri, 2015, pp. 67-73). Dasar pentingnya akhlak dalam As-Sunah dijelaskan oleh Rasulullah Saw. dalam sabdanya: Dari Abu Hurairah r.a berkata: Bahwasanya Rasulullah Saw. bersabda "Sesungguhnya aku diutus hanyalah untuk menyempurnakan akblak yang baik". (HR. Ahmad dan Baihaqi).

Pendidikan tidak hanya dibebani tugas mencerdaskan anak didik dari segi kognitif saja, akan tetapi kecerdasan dari segi afektif dan psikomotorik tugas harus diperhatikan. Dalam hal ini beban pendidikan yang berkaitan dengan kecerdasan afektif siswa adalah upaya membina moral (akhlak) peserta didik. Moral yang diharapkan adalah moral yang menjunjung tinggi nilai-nilai kemanusiaan yang disandarkan pada keyakinan beragama. Akan tetapi untuk mewujudkan hal tersebut dewasa ini tampaknya banyak kendala yang harus dihadapi. Munculnya isu kemerosotan martabat manusia (dehumanisasi) yang muncul akhir-akhir ini. Dapat diduga akibat krisis moral. Krisis moral terjadi antara lain akibat ketidak berimbangnya antara kemajuan "IPTEK" dan "IMTAQ" (Wajdi, 2016, pp. 69-70).

Dalam bidang pendidikan akhlak, Syekh Kholil Bangkalan telah mendirikan beberapa pesantren dan pengajian-pengajian di tiap-tiap cabang dan ranting. Baik pada masa penjajahan Belanda maupun pada masa penguasa Jepang, K.H Kholil Bangkalan tetap memajukan pesantren-pesantren serta mengadakan tabligh dan pengajian-pengajian. Hal itu berkat adanya sistem pendidikan akhlak yang digunakan oleh Syekh Kholil Bangkalan, sistem pendidikan akhlak yang digunakan Syekh Kholil Bangkalan adalah menggunakan metode akhlak seorang Akhlak Murid dalam Belajar, Akhlak Murid kepada Guru, dan Guru dalam mengajar.

Menurut Syekh Kholil Bangkalan, materi pengajaran yang diberikan di pesantren Tebuireng adalah lebih menitikberatkan kepada ilmu-ilmu agama dan bahasa Arab. Namun setelah ada perubahan sistem pendidikan yang ada di pesantren Bangkalan Madura, maka materi yang diajarkan dibagi menjadi dua, yaitu: (1) Materi-materi yang bersifat keagamaan dengan menggunakan bukubuku yang ditulis dengan bahasa Arab atau bahasa Alquran, misalnya seperti Alquran, bahasa Arab, Ushul Fiqh, Hadits, Kitab Kuning, dan lain-lain yang berhubungan dengan materi-materi keagamaan. (2) Kedua adalah materi yang bersifat umum, atau dengan kata lain materi-materi non-keagamaan dengan menggunakan buku-buku yang ditulis dengan bahasa latin, misalnya seperti 
membaca dan menulis bahasa latin, bahasa Indonesia, ilmu bumi, sejarah Indonesia, dan ilmu hitung (Bungin, 2007, pp. 126-128).

Selain membekali santrinya dengan ilmu-ilmu lahir (eksoterik) yang sangat ketat- santrinya juga tidak diperbolehkan boyong (pulang kampung) sebelum hafal seribu nadzamAlfiyah Ibn Malik. Dalam setiap dakwahnya maupun dalam menerima pengaduan permasalahan selalu dikaitkan dengan bait Alfiyah Ibn Malik, jika seseorang menanyakan soal aqidah, maka Syekh Kholil menjawab dengan bait Alfiyah, begitupun dengan permasalah taSaw.uf dan fiqih beliau menjawab dengan bait-bait Alfiyah (Bakhri, 2015, p. 80).

Bahkan pernah terjadi suatu ketika Syekh Kholil berada dalam suatu undangan, beliau memakan makanan langsung menggunakan tangannya tanpa menggunakan sendok lantas menuai kritikkan dari orang lain, langsung saja dengan senyuman Syekh menjawabnya dengan bait-bait Alfiyah. Sehingga dapat disimpulkan bahwa isi dari Alfiyah bisa mencakup berbagai solusi dari berbagai masalah yang timbul kehidupan mulai dari masalah yang sepele sampai yang rumit sebagaimana yang dicontohkan dalam kehidupan Syekh Kholil Bangkalan. Selain itu, beliau juga menggembleng santrinya dengan ilmu batin (Esoterik) (Bakhri, 2015, p. 80).

\section{Simpulan}

Kesimpulan mengenai Pendidikan Akhlak menurut Syekh Kholil Bangkalan dapat digaris bawahi bahwa penyebaran pendidikan akhlak yang disebar luaskan oleh Syekh Kholil Bangkalan sangat mempengaruhi sekali dengan pola pikir orang-orang awam yang pada saat itu masih mempercayai hal-hal yang mistis sehingga dengan adanya pendidikan akhlak ini masyarakat umat Islam pada zaman modern sekarang sudah stabil baik dari kerpribadiannya maupun agamanya.

\section{DAFTAR PUSTAKA}

Bakhri, M. S. (2015). Maha Guru Pesantren, Kisah Perjalanan Hidup Ulama Legendaris. Madura: Erlangga.

Bungin, B. (2007). Metodologi Penelitian Kualitatif Aktualisasi Metodologis ke Arah Ragam Varian Kontemporer. Jakarta: PT Raja Grafindo Persada.

Salim, A. (2001). Teori dan Paradigma Penelitian Sosial. Yogyakarta: PT Tiara Wacana. 
Setiawan, E. (2017). Konsep Pendidikan Akhlak Anak Perspektif Al-Ghazali. Jurnal Kependidikan, Volume 5 Nomor 1.

Sirait, I., Siddik, D., \& Zubaidah, S. (2017). Implementasi Pendidikan Akhlak dalam Pengembangan Karakter di Madrasah Aliyah Negeri 1 Medan. Edu Riligia, Volume 1 Nomor 4.

Siregar, M. (2007). Pemikiran Pendidikan Syeikh Nawawi Al-Bantani. Yogyakarta: Datamedia.

Wajdi, M. F. (2016). Karamah Tiga Sufi. Jakarta: Qalam Publishing. 
